\title{
Comunicação partidária: a estratégia comunista durante a ditadura militar brasileira
}

\section{RESUMO}

Neste artigo iremos pesquisar o papel que a imprensa do Partido Comunista do Brasil (PCdoB) teve nos anos 1970 na sobrevivência do partido diante do agudo quadro de perseguições por ele sofrido. Partimos da hipótese que este jornal estava inserido num circuito comunicativo do partido cuja ênfase primordial era efetivar entre os militantes o mito da revolução mesmo diante da mais severa crise e da opção velada do partido pela via eleitoral após o fracasso da guerrilha do Araguaia. Para sustentarmos este argumento, trabalhamos com os conceitos de rede de comunicação e comunidade imaginada.

\section{PALAVRAS-CHAVE}

Partido Comunista do Brasil

Comunicação

Ditadura

Party communication: the communist strategy during Brazilian military dictatorship

\section{ABSTRACT}

In this article we will search the role that the press of the Communist Party of Brazil (PCdoB) had in the 1970s in the survival of the party before the acute framework of persecution he suffered. Our hypothesis is that this paper was inserted into a communication circuit of the party whose primary emphasis was to effect the militants among the myth of revolution even before the most severe financial crisis and the hidden option of the party by the electoral process after the failure of the Araguaia guerrilla. To sustain this argument, we work with the concepts of network communication and imagined community.

\section{KEYWORDS}

Communist Party of Brazil

Communication

Dictatorship

\section{Marco Antônio Roxo da Silva \\ Professor do Curso de Comunicação Social da UFF/RJ/BR marcoroxo@urbi.com.br}

\section{Mônica Mourão \\ Professora do Curso de Comunicação Social da FAC/CE/BR monicamourao@gmail.com}

Este artigo visa tratar do tema mídia e ditadura militar observando o tipo de comunicação utilizada pelos militantes do Partido Comunista do Brasil, PCdoB no transcurso da década de 1970 . Isto se justifica no fato das pesquisas, em geral, quando se referem aos comunistas, na grande mídia (Mariani, 1998) ou na comunicação realizada por eles (Serra, 2007), focarem-se sobre o Partido Comunista Brasileiro, PCB. Portanto, há um vácuo quando a discussão envolve o PCdoB.

$\mathrm{O}$ único partido de tradição marxista-leninista ainda existente, o PCdoB foi fundado em 1962 como um pequeno partido clandestino de quadros. O Partido se engajou no Movimento Democrático Brasileiro, em 1983, se tornou legal em 1985, apoiou a oposição no Colégio Eleitoral e o primeiro governo da Nova República. Em 1987, passou a ser oposição ao governo Sarney e apesar de acusar o Partido dos Trabalhadores de ser um representante da social democracia a serviço do capitalismo, se incorporou em 1989 à Frente Brasil Popular que apoiou a candidatura de Luiz Inácio Lula da Silva. Em 2002, junto com o PT, chegou ao governo federal.

Assim, o objetivo deste artigo, é discutir o papel que a imprensa do PCdoB teve nos anos 1970 para ajudar o Partido a suportar esse agudo quadro de crise. De forma mais específica, queremos entender o lugar ocupado pelo jornal A Classe Operária, órgão oficial do partido, 
na manutenção da identidade partidária nesse período. Partimos da hipótese que este jornal estava inserido num circuito comunicativo do partido cuja ênfase primordial era efetivar entre os militantes o mito da revolução mesmo diante da mais severa crise e da opção velada do partido pela via eleitoral após o fracasso da guerrilha do Araguaia.

Neste sentido, o artigo está dividido da seguinte forma: na primeira parte apresentaremos uma sintética história do PCdoB, pontuando a importância de $A$ Classe Operária para ele sustentar a sua identidade e se distinguir das outras correntes de esquerda reformistas ou revolucionárias. Depois, vamos partir para a análise do jornal com o intuito de discutir como $A$ Classe Operária se inseria nas estratégias discursivas do $\mathrm{PCdoB}$ e de que forma seu conjunto narrativo permitia os seus leitores e militantes apreender o Partido como uma "comunidade imaginada".

É preciso ressaltar que analisamos os exemplares entre 1975 e 1979 não apenas por ser um período de distensão política, mas pelo fato do PCdoB uma acentuação dos seus dilemas diante da morte dos seus militantes pela ditadura e do intenso e tenso debate interno sobre o significado da experiência no Araguaia.

\section{O PCdoB e sua história}

A Classe Operária, no entanto, sempre encontrou meios e formas de levar a orientação do Partido a seus militantes e aos setores avançados do proletariado e do povo. As forças reacionárias e fascistas jamais conseguiram silenciá-las em definitivo. Também os revisionistas tentaram fazê-lo, por manobras escusas, mas falharam. É que, em sua renegação dos objetivos revolucionários, os revisionistas, chefiados por Prestes, pretenderam logo depois de 1957, acabar com a tradição combativa da imprensa do Partido. Sentiam particular repugnância por tudo que cheirasse a proletário dizendo que a palavra traduzia sectarismo. Chegaram, então, a abandonar o nome "Voz Operária", que em certo período substituíra "A Classe Operária". A esta, davam-na como inexistente para todo o sempre. De modo que, quando a viram voltar a circular à circulação, em 1962, ficaram furiosos, trataram de ignorá-la (A Classe Operária, no 97, maio de 1975).
O jornal A Classe Operária é o órgão oficial do PCdoB. Suas condições de produção e, principalmente, circulação do periódico eram extremamente difíceis em 1975. Dois anos antes, o coordenador do jornal, Lincoln Oest foi assassinado e a equipe que ele dirigia, presa pelo DOI-CODI. Daí em diante, a produção do jornal passou a contar com a colaboração de militantes oriundos da Ação Popular que se integraram ao PCdoB, entre eles Carlos Azevedo, jornalista do grupo fundador da revista Realidade e com passagens pelo O Estado de S. Paulo, e Bernardo Joffily, atual editor do site Vermelho. Eles editavam o jornal da AP, Libertação, incorporado às estruturas comunicativas do $\mathrm{PCdoB}$ e passaram a colaborar com A Classe Operária.

Com o extermínio da guerrilha do Araguaia o quadro piorou. $\mathrm{O}$ jornal era pautado e escrito pelos dirigentes do PCdoB, como João Amazonas e Pedro Pomar, e confeccionado com o auxílio de militantes, como Azevedo, que colaborava com informações e dados para os dirigentes elaborarem os seus artigos. Sua distribuição era feita de forma bastante original e criativa. $\mathrm{O}$ material produzido era enviado para Tirana, capital da Albânia, para que pudesse ser transmitido da pelos militantes jornalistas que, como Joffily, que desde 1974 trabalhavam na Rádio Tirana.

A transmissão era captada no todo ou em partes, gravada e o material transcrito por militantes espalhados pelo Brasil. Estes colocavam suas transcrições no correio para pessoas responsáveis pela impressão do jornal. Estas estavam espalhadas por regiões e tinham a missão de distribuir o jornal através do contato face a face com outros militantes e simpatizantes do PCdoB, que liam e redistribuíam o jornal. Por questões de segurança, essa cadeia de produção, circulação e consumo procurava se manter no anonimato e mudava de local de operação constantemente.

Podemos, assim, compreender melhor a primeira frase da epígrafe que abre esta parte do artigo, no qual o narrador anônimo afirma que "A Classe Operária sempre encontrou meios e formas de levar a orientação do Partido aos seus militantes e aos setores avançados do proletariado". As forças reacionárias e fascistas eram, obviamente, os militares que comandavam a ditadura e sua rede de apoio. E os "revisionistas" eram os militantes do Partido Comunista Brasileiro que, comandados por Luiz Carlos Prestes, retiraram A Classe Operária de circulação em 1957 e levaram o PCB no ano seguinte aderir ao gradualismo reformista. Mas qual o peso que 
a rivalidade com o PCB tinha para a manutenção da identidade do PCdoB? Esta resposta exige um breve exame histórico.

O PCdoB foi fundado em 1962 por um grupo de militantes expulsos do PCB. O acontecimento que deflagrou esse processo foram as denúncias dos crimes praticados por Stalin no XX Congresso do Partido Comunista da União Soviética em 1956. Daí em diante, o antigo Partido Comunista do Brasil, fundado em 1922 e cuja sigla era PCB, se dividiu em duas correntes. A primeira, após a postura vacilante do seu líder, Luiz Carlos Prestes, passou a advogar uma profunda autocrítica pública do stalinismo (processo denominado de "desestalinização") acompanhada de uma revisão das formulações radicais que orientavam a ação política do PCB contidas no Manifesto de 1950.

A outra corrente tinha como expoentes quadros como João Amazonas, Maurício Grabois, Diógenes Arruda Câmara e Pedro Pomar. Era mais heterogênea, mas, em linhas gerais, propunha mudanças limitadas na linha política, sem abalar de forma contundente a ortodoxia partidária calcada no stalinismo. A Declaração de Março de 1958 significou a vitória do primeiro grupo e uma reorientação na ação política do partido, com sua adesão ao reformismo, à defesa de uma política de alianças com o bloco nacional desenvolvimentista e de um modelo econômico caracterizado como "democrático-burguês".

A crise se aprofundou em 1961. A direção do PCB mudou os estatutos do partido de modo a alterar seu nome. Ele passou a se chamar Partido Comunista Brasileiro como forma de demonstrar a quebra de vínculo com a União Soviética. Retirou também as referências ao marxismo-leninismo e ao objetivo de promover a "ditadura do proletariado" para viabilizar sua legalização junto ao TSE. Em contrapartida, o grupo oposicionista redigiu um abaixo-assinado (A Carta dos Cem) acusando o Comitê Central de criar um partido sem alma e expressão revolucionária.

Acusados de "divisionistas", os signatários do documento foram expulsos da legenda e em 1962 promoveram uma Conferência Nacional Extraordinária para "reorganizar" o verdadeiro Partido Comunista do Brasil, fundado em 1922, mantendo este nome e alterando a sigla para PCdoB. Dentro desse processo de "reorganização", recuperar A Classe Operária como órgão oficial do partido foi estratégico para a preservação da memória e da identidade partidária.

Isto porque o grupo fundador do velho PCB editava uma revista chamada Movimento Communista. Acusados de serem "pequenos-burgueses", esses militantes seguiram a determinação da Agência de Propaganda para América do Sul da Internacional Comunista, fecharam a revista e criaram um jornal "operário e de massas". A Classe Operária começou a circular no dia $1^{\circ}$ de maio de 1925 com o objetivo de divulgar o marxismo entre os trabalhadores brasileiros e facilitar o recrutamento de novos militantes, bem como a criação, organização e expansão de núcleos, células e comitês operários para o partido (Mourão, 2009; Morais, 1994).

A Classe Operária foi fechada pela repressão três meses depois. Voltou a circular no $1^{\circ}$ de maio de 1928 e em meados de 1929 teve sua sede invadida e depredada, passando a circular clandestinamente. Junto com $A$ Manbã, editada por Pedro Motta Lima, se tornou portavoz do levante de 1935. Com o fracasso da Insurreição, sua oficina no Rio de Janeiro foi descoberta pela polícia. Isto obrigou a redação se transferir para Salvador e São Paulo. Mas não adiantou. Sua circulação foi diminuindo durante o Estado Novo na medida em que as células comunistas iam sendo desbaratadas.

Entre 1945 e 1947, o PCB passou por uma fase de legalidade e ampliou sua rede de jornais. Porém, com a Guerra Fria, a conjuntura interna mudou. Num expediente tático, a direção do PCB mudou o nome de vários jornais, mas o partido foi posto na ilegalidade pelo TSE em 7 de maio de 1947. Daí em diante, $A$ Voz. Operária se tornou o órgão central do PCB, circulando de forma clandestina. A Classe Operária voltou a circular em 1953, editada por Maurício Grabois, que pretendia nas suas páginas retomar seu objetivo inicial e "desenvolver com mais amplitude a propaganda do marxismoleninismo". Porém, constantes apreensões inviabilizaram a empreitada, levando-a a sair de circulação em 1957 (Morais, 1994).

Assim pode-se compreender melhor a importância do lançamento de A Classe Operária em 1962.

\section{0 jornal foi fundamental na estrafégia do PCdoB em se apropriar da memória e história de luta do comunismo no Brasil, vilipendiada pelos seguidores de Prestes.}


Tendo Maurício Grabois como diretor e Pedro Pomar como editor, o jornal foi o principal eixo interlocução do Partido na produção de um discurso cujo objetivo era convencer seus militantes e interlocutores do que o PCdoB era o autêntico e único representante das tradições marxistas-leninistas no Brasil. Através da reedição de $A$ Classe Operária, o $\mathrm{PCdoB}$ passou a afirmar sua autoridade moral para se apropriar do patrimônio deixado pelo partido fundado em 1922 (Mourão, 2009; Sales 2007).

Foi desta forma que o PCdoB enfrentou, de um lado, o imenso prestígio que PCB tinha no início dos anos 1960 no campo político cultural, e de outro, organizações de esquerda como a Ação Popular, AP, POR, Partido Operário Revolucionário e ORM-POLOP, Organização Revolucionária Marxista-Política Operária, fundadas entre 1960 e para as quais a ortodoxia soviética do PCB e stalinista do PCdoB não fazia sentido e a revolução socialista era tarefa imediata. Para se distinguir do PCB, o PCdoB adotou uma retórica revolucionária cujo modelo era o da guerra popular prolongada, fornecido pelo Partido Comunista Chinês, ainda fiel a ortodoxia stalinista.

A questão é que para se distinguir das outras correntes de esquerda e advogar o status de herdeiro das tradições do "velho PCB", o PCdoB se manteve fiel aos marcos teórico da III Internacional, que observava o advento do socialismo como fruto de um processo gradual, evolutivo e feito por etapas. Neste sentido, o partido defendia que a revolução tivesse um caráter "democrático", devendo ser antecedida por uma política de alianças de amplos setores a serem comandados pelo operariado. Após o golpe de 1964, o partido passou a defender a formação de uma nova Assembléia Constituinte, tornando o uso da violência revolucionária sujeito ao sucesso ou não da via eleitoral (Sales, 2007).

Esse dualismo tático-estratégico (Gorender, 1998) vai se explicitar no documento que resultou das discussões da VI Conferência realizada pelo Partido em 1966. A hesitação do PCdoB no enfrentamento armado com o regime militar vai provocar descontentamento num grupo de militantes que queria ver o Partido distanciado imediatamente do pacifismo do PCB. Este grupo dissidente vai formar o PCdoB-Ala Vermelha ${ }^{1}$.

As divergências internas no $\mathrm{PCdoB}$ sobre a forma de se dirigir a luta armada só acalmaram quando parte de seus militantes entrou efetivamente em luta contra o exército brasileiro na região do Araguaia em 1972. Foi a partir deste momento, que partes dos militantes da Ação
Popular, AP, ingressaram no PCdoB, devido ao status de partido revolucionário que a legenda adquiriu.

Assim, podemos retornar novamente a epígrafe. Em 1975, com quase todas as organizações da esquerda clandestina desarticuladas pela ditadura militar, o PCdoB retomou as polêmicas com seu grande inimigo no campo da esquerda, o PCB, acusando o partido de revisionismo. Tal estratégia discursiva era importante para manutenção da unidade partidária naquela conjuntura em que os militantes estavam ansiosos para saber o que efetivamente aconteceu no Araguaia. O silêncio do Partido foi quebrado um ano depois, quando o PCdoB admitiu ter sofrido um "temporário retrocesso na guerrilha" (Sales, 2007).

Mas isto foi suficiente para abrir uma longa e tensa discussão interna sobre os significados da luta guerrilheira no campo. De um lado estava Ângelo Arroyo, sobrevivente da guerrilha e para qual a mesma, apesar de prescindir do trabalho de massa, havia sido positiva. De outro, Pedro Pomar sustentava que a experiência resultara numa derrota estratégica, política e militar do partido. Uma outra reunião, em dezembro de 1976, foi interceptada pela polícia que assassinou três lideranças do partido, Pedro Pomar, Ângelo Arroyo e João Batista Andrade Drumond, num episódio conhecido como Massacre da Lapa.

A partir daí o $\mathrm{PCdoB}$ ficou praticamente desarticulado. O Comitê Central passou a operar no exterior sob a liderança de João Amazonas. Mas manteve aqui no Brasil suas estruturas comunicativas operando através de $A$ Classe Operária, que continuava com um método de produção bastante artesanal e com a atuação de seus militantes jornalistas nos jornais alternativos, especialmente em O Movimento (Kucinski, 1991). Desta forma, o PCdoB tentava manter sua unidade e se comunicar com um público simpatizante de um ideário de esquerda, além de por o que sobrou de sua rede de militantes no esquema de distribuição do seu órgão oficial.

\section{O PCdoB como comunidade imaginada}

O processo de comunicação sempre envolveu discussão e sociabilidade. Decorre de um trabalho de assimilação das informações em grupos, o que implica a criação de uma consciência coletiva ou opinião pública (Darnton, 1998). Isto nos permite pensar a comunicação como processo que envolve a formação de redes comunicativas e que se compreenda o jornal 
como instrumento potencial para reforçar e ampliar sentimentos coletivos.

Os grupos sociais sempre tiveram como prática reportar acontecimentos que diziam respeito às suas comunidades, como desastres naturais, guerras e outros eventos, num esforço de sobrevivência ou simplesmente por trivialidades e o gosto pela fofoca. As maneiras de reportar esses eventos é que mudaram, porém, convivem com outras antigas como parábolas e lendas (Carey, 2007).

Uma das raízes etimológicas da palavra comunicação a interpreta como "tornar comum" ou "comungar". Desta forma, é factível se pensar que os indivíduos leem jornal para ficar informados, compartilhar de um mesmo mundo e reforçar os laços de pertencimento com os membros de sua comunidade.

\section{A leifura de um jornal é uma forma de se manter relações sociais com indivíduos para além de relações face a face, colaborando para que} os mesmos reforcem suas crenças comuns e fenham a mesma "leifura" do que percebem como "realidade" (Carey, 2007).

Zelizer (1992) pensa os jornalistas como autoridades culturais que utilizam recursos narrativos, tecnológicos e institucionais para se afirmarem como porta-vozes legitimados dos eventos da "vida real". Eles são responsáveis pelos rituais públicos de leitura e guardiões da memória coletiva de sua comunidade. No caso de $A$ Classe Operária, esta autoridade seria reforçada por uma instituição fora da instância midiática, o partido político.

Neste sentido, A Classe Operária utilizava um conjunto de recursos narrativos distinto do padrão de jornalismo que se hegemonizou no Brasil a partir das reformas da década de 1950 (Ribeiro, 2007). Sua preocupação primeira era fidelizar e reforçar os laços de solidariedade entre os militantes do PCdoB com o partido e entre si.
Evidentemente que isto tinha um preço, a dificuldade em transformar o jornal em um órgão de comunicação de massa.

Isto nos permite pensar o PCdoB como uma comunidade imaginada (Anderson, 2008), pois ele é também resultante do conjunto de narrativas produzidas pelos jornalistas militantes ou membros do Comitê Central que escreviam em $A$ Classe Operária. Essas narrativas circularam entre os membros do partido permitindo que, apesar das defecções, separações, expurgos, o PCdoB atravessasse o período da ditadura se mantendo como na sua fundação: um pequeno partido de quadros unido ideologicamente pelo marxismoleninismo e pelo stalinismo, sendo dotado de "quadro teórico" da realidade brasileira similar ao esboçado pelo antigo PCB, apesar do esforço para distinguir deste.

Assim,

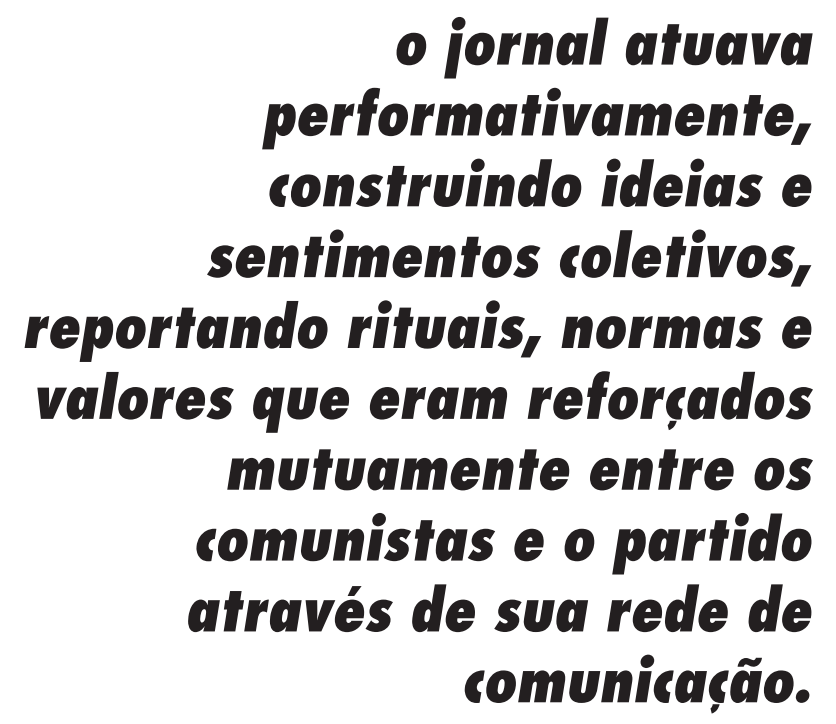

Esse era o seu principal objetivo, mas não o único. Ao observar seus textos no período de abertura política, entre 1975 e 1979, identificamos um conjunto de funções referenciadas pelas seguintes categorias: 1) resolução; 2) disciplina partidária; 3) análise; 4) apelo à ação $\mathrm{e}$ 5) comemoração (Pereira, 2009).

As resoluções são documentos orientadores das diretrizes políticas e ideológicas do partido. São textos de caráter normativo, fruto de deliberações coletivas resultantes de Congressos, Conferências e Encontros, ratificadas pelo Comitê Central, principal instância de poder. As resolucoões, de forma geral, exercem um papel ritual de imputar aos militantes a hierarquia partidária e a 
conduta que o Partido espera de cada um.

As decisões adotadas pela VII Conferência - já ratificadas pelo Comitê Central - precisam ser levadas ao conjunto do Partido, discutidas e assimiladas por todos comunistas, a fim de que se transformem em linha comum de atuação partidária. Elas podem e devem ser enriquecidas com as contribuições de cada militante de modo a concretizar em cada organismo as tarefas ali indicadas. É imperioso organizar a luta pela aplicação das decisões da VII Conferência, o que significa por em prática de maneira criativa o conteúdo destas resoluções e fazê-las chegar às grandes massas trabalhadoras e populares (A Classe Operária, no 137, junho de 1979, p.13).

A segunda categoria é a disciplina partidária. Enquanto as resoluções dizem respeito a parâmetros coletivos de conduta, os textos que reforçam a disciplina partidária se referem ao militante através de casos exemplares. A meta principal aqui é sustentar, fazer o militante comunista agir de acordo com os princípios partidários do Leninismo e do Stalinismo: ele deve se comportar como um soldado do partido e atuar na linha de frente pelo socialismo. Este ideal deveria estar acima de quaisquer divergências internas (Pereira, 2009).

O comportamento de Luiz Medeiros serve de exemplo ao povo em geral, à juventude e, em especial, aos comunistas. É o modo correto de proceder todo aquele que subordina os seus interesses individuais aos objetivos maiores da revolução e que, se cai na mão do regime terrorista, defende a causa e não sua pessoa, mesmo ante as piores atrocidades físicas e morais perpetuadas pelos bandidos fascistas, não compromete a luta nem a organização a que pertence, peleja por manter-se vivo, morre se for preciso, mas jamais, em nenhuma hipótese sucumbe moralmente. É na linha desses exemplos dignificantes que vai se salientando a luta no Brasil de hoje e que vão se forjando os grandes nomes do povo, seus mártires e seus heróis [...] (A Classe Operária, no 108, jul 1976, p. 11-12).
Os textos da disciplina partidária visam, então, reforçar uma visão mítica do partido, do proletariado e da própria revolução (Pereira, 2009). Conforme Sorel (1992) o mito é uma ideia-força que uma vez instaurada na consciência coletiva permite a mesma adquirir certa dimensão espiritual dotando o grupo de uma fé em "verdades", que por serem irracionais, levam a ação e não a reflexão. Neste aspecto, ele se aproxima de dogma sagrado conforme a definição de Eliade (1972). A ortodoxia marxisma é um exemplo.

\section{A inevifabilidade da revolução se sustenta no materialismo histórico, pois o socialismo é o último estágio evolutivo da sociedade a ser conquistado pela ação do prolefariado.}

Marx apresentou na forma de teoria aquilo que na realidade é um artifício, uma profecia, para incrementar a luta política. O exemplo de Medeiros tinha o sentido de mostrar para os militantes do PCdoB que a revolução socialista era uma "verdade" incontestável.

As duas categorias seguintes, análise e apelo à ação caminham relativamente juntas mesclando duas funções pensadas por Lênin para a o sistema de comunicação de um partido comunista: a propaganda e a agitação. A primeira consistiria na análise profunda de todas as causas de um determinado problema com o fim de incentivar a ação criativa dos militantes que compunham a vanguarda do partido operário. A segunda composta por folhetos e discursos orais deveria ser dirigida aos proletários sem orgulho de pertencer a sua classe (Pereira, 2009).

Para se entender como operava essa combinação no interior de A Classe Operária se faz necessário retomar o olhar sobre a conjuntura. Em 1976, o PCdoB admitiu de forma pública ter tido sérios contratempos no Araguaia. A admissão da derrota levou o partido a um intenso e desgastante debate interno. À perda de militantes na guerrilha se somou o assassinato de dirigentes com o "Massacre da Lapa". A principal missão dos dirigentes, neste contexto era rearticular o partido e buscar formas de ação de modo a manter a unidade e a identidade partidária em meio às intensas divergências internas 
provocadas pela análise interna feita sobre a experiência do Araguaia (Pereira, 2009).

O partido retomou o seu "dualismo táticoestratégico", combinando novamente a via eleitoral, forma de consolidar a etapa democrática com a retórica revolucionária.

Ou se trata de aceitar as reformas da grande burguesia e do imperialismo que desembocarão numa democracia relativa com indeléveis sobrevivências da ditadura. Ou se ousa vencer e se faz avançar a luta de massas, em todos os níveis e sob todas as formas. Buscando, na atual etapa, ampliar ao máximo as conquistas democráticas pela via de uma Constituinte livremente eleita. E com a certeza de que se algo mudou foi, sem dúvida, a correlação subjetiva entre as forças sociais em choque, alargando tremendamente as fileiras da frente democrática e exaurindo o campo da ditadura. O que resta agora é saber transformar esse acúmulo subjetivo de forças em ação independente de massas (A Classe Operária, no 123, fev. 1978, p. 23).

A ênfase no "trabalho de massas" era uma forma de mostrar que o partido não estava inativo. E a experiência do Araguaia tinha de ser positivada para o Partido manter sua áurea revolucionária. $\mathrm{E}$ isto foi feito quando o PCdoB elegeu o documento de Ângelo Arroyo positivando essa experiência como a versão oficial sobre a luta guerrilheira ${ }^{2}$.

Cabe a nós, militantes do PCdoB, o dever imperioso de ajudar as massas a fazerem a sua experiência e simultaneamente desper$\operatorname{tar}$ a sua consciência revolucionária. Somente assim estaremos aproveitando a fase de transição que atravessamos de maneira a ir formando o exército político capaz de conduzir a causa popular à vitória (A Classe Operária, no 134, fev/mar de 1979, p. 11).

Esse processo de manutenção dos ideais da revolução aponta para o lugar reverencial que a memória do Araguaia passou a ocupar na memória partidária. Ela ilustra, de certa forma, o peso da última categoria de análise, a comemoração (Pereira, 2009).

\begin{abstract}
Neste mês de abril comemora-se o quinto aniversário da resistência armada do Araguaia, acontecimento de extraordinária significação na vida do país. Desfraldando a bandeira da liberdade e dos direitos do povo, moradores do sul do Pará enfrentaram o banditismo de poderosas forças de reação e, com sua bravura e seu sangue, escreveram uma das mais belas histórias das lutas populares no Brasil. Não temeram sacrifícios, jamais vacilaram nos propósitos que os animavam. Indicaram, com o seu exemplo o caminho da libertação nacional e social, o caminho da guerra popular (A Classe Operária, no 114, mar/abr 1977, p. 6).
\end{abstract}

Assim, mesmo diante da configuração que tomou conta da dinâmica política com o retorno do pluripartidarismo e a presença do novo sindicalismo do qual o PCdoB inicialmente não fez parte por ele atacar a Nova República, o circuito comunicativo do PCdoB ainda se restringia, no início dos anos 1980, aos militantes do partido. Desta forma, quando se fala em frente ampla da oposição à ditadura, não se pode perder de vista que boa parte dos militantes do PCdoB ainda se imaginava e ao Partido como a vanguarda que levaria a frente essa luta e, posteriormente, detonaria a explosão revolucionária. Esse credo se manteve mesmo diante da participação do partido em eleições, primeiro no interior do Movimento Democrático Brasileiro e depois, na legalidade na Assembléia Constituinte e em aliança com o PT em 1989 (Sales, 2007).

\section{REFERÊNCIAS}

ANDERSON, Benedict. Comunidades Imaginadas. São Paulo: Cia das Letras, 2008.

CAREY, James W. A Short History of Journalism for Journalists: A Proposal and Essay. In: The Harvard International Journal of Press/Politics; dezembro de 2007.

CAREY, James W. Communication as culture: essays on media and society. Boston: Unwin Hyman, 1989.

DARNTON, Robert. Os best-sellers proibidos na França 
pré-revolucionária. São Paulo: Companhia das Letras, 1998.

EM DEFESA DO PARTIDO. Carta dos 100. Disponível em: <http://www.vermelho.org.br/pcdob/80anos/ docshists/1961.asp.> Acesso em: 23 jul 2007.

ELIADE, Mircea. Mito e Realidade. São Paulo: Perspectiva, 1992.

KUCINSKI, Bernardo. Jornalistas e revolucionários: nos tempos da imprensa alternativa. São Paulo: Ed. Página Aberta, 1991.

MARIANI, Bethania. O PCB e a Imprensa - os Comunistas no Imaginário dos Jornais (1922-1989). Rio de Janeiro: Revan; Campinas: UNICAMP, 1998.

PEREIRA, Mônica Mourão. A Esquerda Bem Informada: A Estratégia Política de Comunicação do PCdoB em Dois Tempos. 2009. Dissertação. (Mestrado em Comunicação Social) - Programa de Pós-Graduação em Comunicação Social, UFF, Niterói, 2009.

POLLAK, Michael. Memória, Esquecimento, Silêncio. In: Estudos Históricos, Rio de Janeiro, v. 2, n. 3, p. 3-15, 1989.

SALES, Jean Rodrigues. Da Luta Armada ao Governo Lula: A História do PCdoB. In: REIS, Daniel Aarão \& FERREIRA, Jorge. Revolução e Democracia. Rio de Janeiro: Civilização Brasileira, 2007.

SALES, Jean Rodrigues. A Luta Armada contra a Ditadura Militar. São Paulo: Fundação Perseu Abramo, 2007(a).

SERRA, Sônia. Jornalismo político dos comunistas no Brasil: diretrizes e experiências da "Imprensa Popular". Anais do II Congresso da Associação Brasileira de Pesquisadores de Comunicaşão e Política, 2007. Disponível em: <http:// www.fafich.ufmg.br/compolitica/anais2007/gt_jmpsonia.pdf.> Acesso em: $10 \mathrm{dez} 2007$.

SOREL, Georges. Reflexões sobre a Violência. São Paulo: Martins Fontes, 1992.

ZELIZER, Barbie. Covering the Body: the Kennedy Assassination, the Media, and the Shaping of Collective Memory. Chicago and London: The University of Chicago Press, 1992.

\section{NOTAS}

${ }^{1}$ Como parte desses militantes já havia recebido treinamento militar na China, tentaram utilizar a teoria do "foquismo", através de ações armadas como assalto a bancos, e o "trabalho de massa" como uma etapa de acumulação de forças para a guerra popular prolongada no campo. Atingido duramente pela repressão, os remanescentes da tendência passaram a criticar o voluntarismo da esquerda revolucionária e se voltaram para o "trabalho de massa" se engajando nos movimentos sociais e sindicais que nos anos 1970 dariam origem ao Partido dos Trabalhadores. Ver: SALES, Jean Rodrigues. A Luta Armada contra a Ditadura Militar. São Paulo: Fundação Perseu Abramo, 2007, p. 89-94.

${ }^{2}$ Essa decisão do Comitê Central foi ratificada pela VII Conferência em 1979. Insatisfeitos, muitos militantes foram expulsos, outros se afastaram. Alguns foram para o PT e outros, como José Genuíno, fundaram o Partido Comunista Revolucionário, PRC, que foi uma tendência do PT se dissolvendo no final dos anos 1980. SALES, Jean Rodrigues. Da Luta Armada ao Governo Lula: A História do PCdoB. In: REIS, Daniel Aarão \& FERREIRA, Jorge. Revolução e Democracia. Rio de Janeiro, Civilização Brasileira, 2007, p. 175. 